\title{
COMMUNITY PERSPECTIVES ON CHILDREN WITH SPECIAL NEEDS
}

\author{
Lee Swee Poh, Mohd Mahzan Awang, and Shahlan Surat
}

\begin{abstract}
This paper discusses the perspectives of local community, family, school and peers on children with special needs (or disabled children) schooling under the Special Education Integrated Program in Bintulu District Education Office, Sarawak, Malaysia. This discussion is done based on the resources of previous researches conducted in Malaysia and other countries, such as the United States, Britain, Italy, and India. Labeling theory and theories of perception are reviewed engaging the social conflicts. Totally 88 respondents from Chinese community had been taken to answer the questionnaire. In general, there is a handful optimistic views that special needs children have their own talent. They are the special gift from God. They can distinguish good and bad. They have influences and roles to play. In addition, the community feels sympathy with them. The community likes to engage with them and believes that they can perform activities very well. Due to environmental impact on the development of individual and social skills of special needs children, the study suggests that Malaysians continue to hold to the principles to provide safe and quality education for special needs children. Efforts need to continue to foster a healthier community awareness and positive support on special needs children so that discrimination can be reduced because every individual has the right to obtain social development and quality of education.
\end{abstract}

\section{KEYWORD:}

special needs children, people with disabilities, community, family, school, peers, special education

\section{INTRODUCTION}

Since 1970s, persons with special need have received worldwide concerns on their equality and quality of life. Various efforts have been made to claim their rights. A balanced development among children with special needs is crucial because it brings a big impact on their future and quality of life. In Malaysia, Education Act 996 (Act 550), Special Education Policy and Malaysia Education Blueprint 2013-2025, always ensures children with special needs to be able to access good quality of education.

Pupils with special needs have a disability in terms of vision, hearing, speech, physical, or learning problems. The category of pupils learning problems covers dyslexia, Attention Deficit Hyperactivity Disorder (ADHD), slow learner, Autism, Down syndrome, and mild retardation. Their learning characteristics are different in terms of the physical, intellectual, social, and personal dimension. They may slower in the development of maturity and intellectual functions. Their attitudes and values are not in line with normal child behavior. However, they still interact with their environment, family members, educators, and friends. Therefore, the perspective of community brought a great influence to their development and lives.
Malaysia has a population of $29,683,685$ people in 2014. According to the statistics of the Social Welfare Department, 531,962 people with disability that are registered during the year, about $1.79 \%$ of the population. The percentage is far from the average $10 \%$ estimated by the United Nations for number of people with disability in developing countries.

The issue becomes more complex when many children with special needs are ignored. By 2014, only 57,637 students attend special education, $10.83 \%$ of the registered person with disability, or $0.19 \%$ of the total population. However, the Action Plan for the Disabled 20162022 target $75 \%$ special needs students in primary and secondary education (the Ministry of women, family, and community, 2016). Does negative perception led to many people refuse to register as special needs group? Could not family members accept persons with disabilities in their family? People with disabilities as one of the members of the community should not be isolated and marginalized from social integration and education opportunities.

Because of efforts by various parties, the number of pupils attending special education has increased (see Table 1). In 2015, there are $5 \%$ pupils with special needs entering special 
education school, $6 \%$ enrolling inclusive education programs, and $89 \%$ admitted to special education Integration program. The level of preparation and the attitude of educators and peers also affect schooling and social life of children with special needs. All ten case studies in the United States found that children with disabilities were two to three times more frequently to be bullied (URAbilityPath.org). The study in Peninsular Malaysia shows the rates of child abuse is 20 percent. The majority of them are abused sexually (Shamsul Amri Effective: 2009). The community considers children with special needs as inferior and could not defend themselves. Such perception certainly affects their learning process in school. Do the negative view also found in Sarawak? For example, in Bintulu, there are 353 registered special children with Association For Concerned Citizen and Parents of Handicapped Children in Bintulu (PERPIKAT) in 2011. Study on the perception of the community must be carried out to protect the welfare and safety of children special needs.

Table 1.

Total Classes, Students and Teachers in Special Education Malaysia (Year 2011 - 2015)

\begin{tabular}{|l|c|c|c|c|c|}
\hline & $\mathbf{2 0 1 1}$ & $\mathbf{2 0 1 2}$ & $\mathbf{2 0 1 3}$ & $\mathbf{2 0 1 4}$ & $\mathbf{2 0 1 5}$ \\
\hline Classes & $\mathbf{7 , 6 9 4}$ & 8,075 & 8,474 & 8,971 & 9,416 \\
\hline Students & 50,237 & 53,983 & 56,406 & 57,637 & 60,875 \\
\hline Teachers & 11,697 & 11,877 & 12,421 & 13,510 & 14,142 \\
\hline
\end{tabular}

(Source: The Book of Data on Special Education 2015, Education Department of Malaysia)

In general, this study was intended to explore the perspectives of communities towards children with special needs who have trouble in learning. Therefore, the objective of this study is to review the positive or negative views of local communities (such as public, leaders, nongovernment organizations, household, etc., family members, educators, and peers) towards children with special needs in terms of development of intellectual, spiritual, emotion, social and physical dimension.

\section{LITERATURE REVIEWS}

According to the theory of labeling and social perception, individual development can be influenced by views and attitudes of the community. The theory of labeling was found by Lemert and Herbert Mead. It was later developed by Howard Becker in 1963. Deviation that is appeared can be caused by labeling made by the community to a person who then tends to be deviant. When we label someone, we tend to treat someone based on the label, and people tend to follow the prescribed label we give. On the other hand, the theory of social perception explains that perception is the process of fixing human stimulus. Senses can be affected and provide meaning or effect. There is some biases or error in social perception: (1) Hallo Effect tends to fix people consistently because individuals generally give perception based on observed effects or characteristics; and (2) Forked Tail Effect (negative halo) exaggerates perception based on a condition measured.

There are many studies of special needs and social circles have been carried out. Some studies show that community gives positive views towards the special needs and always willing to give support. For example, some case studies in Sidon - Lebanon, British, Danish, Spain, Austria, Netherlands, and Norway schools show that social integration, parents involvement, and parents attitude have brought the success of educational inclusion for children with special needs in ordinary schools (Heyam Lutfi ElZein, 2009; UNESCO). Their findings indicate that community, especially employers are optimistic towards intellectual disabled in Jordan and Penang in Malaysia (Asia Community Service: 2006; UNESCO).

However, some studies also show that people have a negative perspective on the special needs. For example, a case study in India has indicated low awareness for children special education. it is especially appeared in civil society, lower class family, and rural districts (Aruba Zubedi and Husna Habib, 2015). In addition, members of the community tend to do the separation towards people with special needs. Many cases of bullying and abuse had occurred (Lineker ak Takom et. al: 2014). In Malaysia, several studies reveal that some employers discriminate people with special needs (Hazlin Falina Rosli, 2015; Siti Hajar Abu Bakar et. al, 2012).

\section{Methodology Of The Study}

This research was conducted through questionnaires. An instrument was built based on five aspects of human development according to the Malaysian National Education Philosophy: intellectual, spiritual, emotional, social, and physical dimension. A total of 20 questions had 
been designed to obtain views of communities on children with special needs and learning disabilities. The community was divided into four categories. They are the local community, family members, educators, and friends. Location of the study was at Bintulu. The selection of targeted sample is Chinese ethnic. This was due to the District Education Office of Bintulu has long started an integrated special education program at national schools. However, the program is newly introduced at two Chinese primary public schools. Therefore, the perspective of the Chinese community is needed to plan future enrolment strategy. Data collection was random. It was focused without controlling the factors of gender and social status. Methods of data analysis carried out descriptively through SPSS version 22.

\section{Findings Of The Review And Discussion}

In total, 88 respondents had been surveyed. They were categorized as the local community, family members, teachers, and friends. The Table 2 below shows the number of the respondents and the respective percentage.

Table 2.

The Profiles of the Respondents

\begin{tabular}{|c|l|c|c|c|}
\hline \multirow{5}{*}{ Items } & Description & Frequency & $\begin{array}{c}\text { Percentage } \\
(\%)\end{array}$ & $\begin{array}{c}\text { Total } \\
\text { respondents }\end{array}$ \\
\hline \multirow{4}{*}{ Categories } & $\begin{array}{l}\text { Local } \\
\text { community }\end{array}$ & 20 & 22.7 & \\
\cline { 2 - 4 } & $\begin{array}{l}\text { Family } \\
\text { members }\end{array}$ & 13 & 14.8 & \\
\cline { 2 - 4 } & Teachers & 21 & 23.9 & \multirow{2}{*}{88} \\
\cline { 2 - 4 } & Friends & 34 & 38.6 & \multirow{2}{*}{8} \\
\hline \multirow{2}{*}{ Gender } & Male & 26 & 29.5 & \\
\cline { 2 - 4 } & Female & 62 & 70.5 & \\
\hline \multirow{2}{*}{$\begin{array}{l}\text { Education } \\
\text { level }\end{array}$} & Primary & 36 & 40.9 & \\
\cline { 2 - 4 } & Secondary & 14 & 15.9 & \\
\cline { 2 - 4 } & & 38 & 43.2 & \\
\hline
\end{tabular}

In this study, the Likert scale was used in the questionnaire -whereby $1=$ strongly disagree; $2=$ disagree; $3=$ not sure; $4=$ agree; and $5=$ strongly agree. The data analysis was to find out overall percentage (\%) for each scale that shown in Table 3 , and the mean for each item is shown in Table 3 .

Table 3.

Data Analysis on Percentage (\%) of Likert Scale

\begin{tabular}{|c|c|c|c|c|c|c|}
\hline & & 1 & 2 & 3 & 4 & 5 \\
\hline \multicolumn{7}{|c|}{ Intellectual dimension } \\
\hline 1 & $\begin{array}{l}\text { I'm less aware of matters relating to special- } \\
\text { needed children. }\end{array}$ & 3.4 & 28.4 & 12.5 & 36.4 & 19.3 \\
\hline 2 & $\begin{array}{l}\text { I know how to help special-needed } \\
\text { children in terms of academic and education. }\end{array}$ & 17.0 & 14.8 & 26.1 & 29.5 & 12.5 \\
\hline 3 & $\begin{array}{l}\text { I am of the view that the special-needed } \\
\text { children were slow in learning. }\end{array}$ & 4.5 & 12.5 & 14.8 & 37.5 & 30.7 \\
\hline 4 & $\begin{array}{l}\text { I am of the view that special-needed } \\
\text { children have efficient intellectual skills. }\end{array}$ & 2.3 & 2.3 & 13.6 & 38.6 & 43.2 \\
\hline \multicolumn{7}{|c|}{ Spiritual dimension } \\
\hline 5 & $\begin{array}{l}\text { I am of the view that special-needed } \\
\text { children is the special grace of God. }\end{array}$ & nil & 9.1 & 10.2 & 43.2 & 37.5 \\
\hline 6 & $\begin{array}{l}\text { I am of the view that special-needed } \\
\text { children know the moral and spiritual matters. }\end{array}$ & 2.3 & 3.4 & 14.8 & 39.8 & 39.8 \\
\hline 7 & $\begin{array}{l}\text { I believe the special-needed children } \\
\text { have influence and role play. }\end{array}$ & 1.1 & 4.5 & 10.2 & 46.6 & 37.5 \\
\hline 8 & $\begin{array}{l}\text { I don't understand the inner world of the special- } \\
\text { needed children. }\end{array}$ & 2.3 & 19.3 & 33.0 & 26.1 & 19.3 \\
\hline \multicolumn{7}{|c|}{ Emotion dimension } \\
\hline 9 & $\begin{array}{l}\text { I feel pity with the fate of the special- } \\
\text { needed children. }\end{array}$ & nil & 6.8 & 6.8 & 47.7 & 38.6 \\
\hline 10 & $\begin{array}{l}\text { I am of the view that special-needed } \\
\text { children are always emotional. }\end{array}$ & 5.7 & 18.2 & 19.3 & 38.6 & 18.2 \\
\hline
\end{tabular}




\begin{tabular}{|c|c|c|c|c|c|c|}
\hline & & 1 & 2 & 3 & 4 & 5 \\
\hline 11 & $\begin{array}{l}\text { I am of the view that special-needed } \\
\text { children could not control their emotions. }\end{array}$ & 10.2 & 22.7 & 23.9 & 21.6 & 21.6 \\
\hline 12 & $\begin{array}{l}\text { I am of the view that special-needed } \\
\text { children do not know how to express } \\
\text { their feelings. }\end{array}$ & 6.8 & 17.0 & 23.9 & 35.2 & 17.0 \\
\hline \multicolumn{7}{|c|}{ Physical dimension } \\
\hline 13 & $\begin{array}{l}\text { I feel difficult to bring special-needed } \\
\text { children to other places. }\end{array}$ & 5.7 & 20.5 & 26.1 & 26.1 & 21.6 \\
\hline 14 & $\begin{array}{l}\text { I think the special-needed children are } \\
\text { always need special facilities to move. }\end{array}$ & 1.1 & 9.1 & 21.6 & 30.7 & 37.5 \\
\hline 15 & $\begin{array}{l}\text { I think the special-needed children could } \\
\text { not follow sports well. }\end{array}$ & 4.5 & 34.1 & 18.2 & 20.5 & 22.7 \\
\hline 16 & $\begin{array}{l}\text { I think the special-needed children are } \\
\text { not able to make hand activities efficiently. }\end{array}$ & 11.4 & 38.6 & 14.8 & 20.5 & 14.8 \\
\hline \multicolumn{7}{|c|}{ Social dimension } \\
\hline 17 & I don't like to mix with special-needed children. & 31.8 & 36.4 & 23.9 & 4.5 & 3.4 \\
\hline 18 & $\begin{array}{l}\text { I don't know how to communicate with the } \\
\text { special-needed children. }\end{array}$ & 8.0 & 23.9 & 22.7 & 29.5 & 15.9 \\
\hline 19 & $\begin{array}{l}\text { I am of the view that special-needed children are } \\
\text { difficult to socialize with other people. }\end{array}$ & 10.2 & 25.0 & 25.0 & 27.3 & 12.5 \\
\hline 20 & $\begin{array}{l}\text { I am of the view that special-needed children } \\
\text { always require the help of other people during } \\
\text { their lifetimes. }\end{array}$ & 6.8 & 22.7 & 12.5 & 28.4 & 29.5 \\
\hline
\end{tabular}

Based on Table 4, social communities admit that they have limited information about children with special need and think that children are slow in learning. However, the communities know how to help the children in learning matters, and the children have specific talent.

Furthermore, the social communities think positively of the children with special-need that they are gifted from God, that they know moral value, and that they have influence on others' life. However, the community not sure about the inner world of the special-needed children.

All communities feel sympathy on the special-need children. They think that the children are emotional and cannot control their emotion. The children also do not know how to express their feelings.

Most people feel pity for the children, and agree that the children are not easy to move. Thus, relevant equipment is necessary. However, the communities view the children can perform well in sport and hand-doing works.

The majority of the community would like to mix with the children, but they do not know how to communicate and they thought the children also difficult to socialize with others. The communities view that the children cannot be totally independent and need assistance from others during their lifespan.

The communities have no doubt on the children's understanding of the moral value and the capability to perform in academic, sport and arts. However, they think that the children might be at a slower pace. Nevertheless, the communities also feel that this "less fortunate" group needs support in terms of equipment for mobility and living in the real life.

Table 4 shows the average perception of each major group in the questionnaire, i.e. local community, family members, teachers, and friends. 
Table 4.

Mean of Each Item

\begin{tabular}{|c|c|c|c|c|c|c|}
\hline & & $\begin{array}{c}\text { Local } \\
\text { community } \\
\end{array}$ & $\begin{array}{l}\text { Family } \\
\text { member }\end{array}$ & Teachers & Friends & Overall \\
\hline \multicolumn{7}{|c|}{ Intellectual dimension } \\
\hline 1 & $\begin{array}{l}\text { I'm less aware of matters relating to special- } \\
\text { needed children. }\end{array}$ & 3.35 & 2.85 & 2.71 & 4.06 & 3.40 \\
\hline 2 & $\begin{array}{l}\text { I know how to help special-needed children } \\
\text { in terms of academic and education. }\end{array}$ & 2.35 & 3.46 & 2.90 & 3.41 & 3.06 \\
\hline 3 & $\begin{array}{l}\text { I am of the view that the special-needed } \\
\text { children were slow in learning. }\end{array}$ & 4.00 & 4.23 & 3.52 & 3.62 & 3.77 \\
\hline 4 & $\begin{array}{l}\text { I am of the view that special-needed } \\
\text { children have efficient intellectual skills }\end{array}$ & 4.00 & 4.31 & 3.95 & 4.38 & 4.18 \\
\hline \multicolumn{7}{|c|}{ Spiritual dimension } \\
\hline 5 & $\begin{array}{l}\text { I am of the view that special-needed } \\
\text { children is the special grace of God. }\end{array}$ & 4.40 & 4.08 & 3.95 & 4.00 & 4.09 \\
\hline 6 & $\begin{array}{l}\text { I am of the view that special-needed } \\
\text { children know the moral and spiritual } \\
\text { matters. }\end{array}$ & 3.60 & 4.15 & 4.10 & 4.41 & 4.11 \\
\hline 7 & $\begin{array}{l}\text { I believe the special-needed children have } \\
\text { influence and role play. }\end{array}$ & 4.20 & 4.15 & 4.29 & 4.03 & 4.15 \\
\hline 8 & $\begin{array}{l}\text { I don't understand the inner world of the } \\
\text { special-needed children. }\end{array}$ & 3.55 & 3.38 & 3.10 & 3.53 & 3.41 \\
\hline \multicolumn{7}{|c|}{ Emotion dimension } \\
\hline 9 & $\begin{array}{l}\text { I feel pity with the fate of the special- } \\
\text { needed children. }\end{array}$ & 4.35 & 3.92 & 4.05 & 4.26 & 4.18 \\
\hline 10 & $\begin{array}{l}\text { I am of the view that special-needed } \\
\text { children are always emotional. }\end{array}$ & 3.95 & 3.85 & 3.00 & 3.29 & 3.45 \\
\hline 11 & $\begin{array}{l}\text { I am of the view that special-needed } \\
\text { children could not control their emotions. }\end{array}$ & 3.75 & 3.62 & 2.76 & 3.03 & 3.22 \\
\hline 12 & $\begin{array}{l}\text { I am of the view that special-needed } \\
\text { children do not know how to express } \\
\text { their feelings. }\end{array}$ & 4.15 & 3.77 & 2.90 & 3.09 & 3.39 \\
\hline \multicolumn{7}{|c|}{ Physical dimension } \\
\hline 13 & $\begin{array}{l}\text { I feel difficult to bring special-needed } \\
\text { children to other places. }\end{array}$ & 3.50 & 3.54 & 3.05 & 3.44 & 3.38 \\
\hline 14 & $\begin{array}{l}\text { I think the special-needed children are } \\
\text { always need special facilities to move. }\end{array}$ & 4.40 & 3.62 & 3.71 & 3.94 & 3.94 \\
\hline 15 & $\begin{array}{l}\text { I think the special-needed children could } \\
\text { not follow sports well. }\end{array}$ & 3.35 & 3.23 & 2.33 & 3.71 & 3.23 \\
\hline 16 & $\begin{array}{l}\text { I think the special-needed children are } \\
\text { not able to make hand activities efficiently. }\end{array}$ & 3.10 & 3.38 & 2.19 & 3.00 & 2.89 \\
\hline \multicolumn{7}{|c|}{ Social dimension } \\
\hline 17 & $\begin{array}{l}\text { I don't like to mix with special-needed } \\
\text { children. }\end{array}$ & 2.45 & 2.23 & 1.48 & 2.26 & 2.11 \\
\hline 18 & $\begin{array}{l}\text { I don't know how to communicate with the } \\
\text { special-needed children. }\end{array}$ & 3.45 & 3.23 & 2.76 & 3.35 & 3.22 \\
\hline
\end{tabular}




\begin{tabular}{|c|l|c|c|c|c|}
\hline 19 & $\begin{array}{c}\text { Local } \\
\text { community }\end{array}$ & $\begin{array}{c}\text { Family } \\
\text { member }\end{array}$ & Teachers & Friends & Overall \\
\hline $\begin{array}{l}\text { children are difficult to socialize with } \\
\text { other people. }\end{array}$ & $\begin{array}{l}\text { I am of the view that special-needed } \\
\text { children always require the help of other } \\
\text { people during their lifetimes. }\end{array}$ & 2.90 & 3.54 & 2.62 & 3.18 \\
\hline
\end{tabular}

For the intellectual dimension, most of the people agree that children with special need have unique talents. Most of the friends admitted that they do not really know a lot about children with special need, meanwhile family and teachers have some information and knowledge about them. Majority of the community does not know the learning technique of children with special need. They are not very sure about the learning pace of children with special need whereby most of them thought that it depends on the criticalness of the disability.

For the spiritual dimension, most of the people agree that children with special need have their own influences and play their roles in society. All categories of response also agree that the children with special need are aware of the right-and-wrong-doing in their minds. On top of that, people have a positive perspective on the children with special need where they believe that the children with special need are the special gift from God. However, people feel confused with the inner world of the children.

For the emotional dimension in turn, on average, the community feels pity with the fate of children with special need. They are not sure whether children with special need often feel emotional, are unable to control emotions and to express their feelings. However, teachers are of the opinion that children with special need are able to control emotions and express their feelings.

For the physical aspect, almost no respondents are sure with the difficulties to move. They are also not sure that the underlying facilities may bring benefits and assistances. They are not sure whether children with a special need can perform sports very well. Most of the teachers disagreed with the limited handwork among children with special need. This is because they found there are some children with a special need who are a very success in sports and art at international level.

For social development aspect, all categories of society prefer to mix with children with special need. The community is not sure about the way to communicate with the children. They are also not sure whether the children can mingle with others. They are not sure whether children with special need help from others along their age because some children with special need live independently while they grow up. The teachers are very positive in the term of socializing with children with special need. Meanwhile, the friends feel children with special need special assistance in their life.

Overall, from the questionnaire, the Chinese ethnic in Bintulu has a positive perspective towards children with special need. The Chinese ethnic is of the opinion that children with special need have their own talent. They are the special gift from God. They can distinguish good or bad things. They have influence and role. In addition, the Chinese people feel sympathy with them, the community likes to engage with them and believes they can make arts activities very well.

However, the majority of the community do not have much understanding about the children with special need. They are not sure on many aspects such as teaching and learning process in special education, the psychological and emotional development, physical movement, communication techniques, and social skills.

\section{Conclusion}

The study indicates that the majority of citizens of Chinese ethnic have a positive perception of children with special need. The children are not excluded socially. However, 
awareness and efforts can be enhanced so that the citizens of Chinese ethnic have a better understanding about the world of children with special need. Help and support are not given only as charity-oriented but as human developmentoriented entities so that they received acclamation of full acceptance in social circles.

\section{REFERENCE}

AbilityPath.org . Walk A Mile In Their Shoes: Bullying and the Child with Special Needs: A Report and Guide.

Aruba Zubedi \& Husna Habib. 2015. Special Needs Education - Awareness And Perspectives In The Community And Schools.

International Journal of Development Research. Vol. 5(2): 3365-3369.

Asia Community Service. 2006.

Hasnah binti Mahasan. 1997. Sambutan Masyarakat Terhadap OKU: Satu Percepsi Mereka Sendiri di Pusat Pemulihan Samarahan.

Latihan Ilmiah Sarjanamuda Sains Sosial Dengan Kepujian Pengurusan Khidmat Sosial. Fakulti Sains Sosial, Universiti Malaysia Sarawak.

Heyam Lutfi ElZein. 2009. Attitudes toward inclusion of children with special needs in regular schools (A case study from parents' perspective). Educational Research and Review, Vol.4(4):164-172.

http://documents.tips / documents/statistikorang-kurang-upaya.html

http:// pmr.penerangan.gov.my/index.php/ pendidikan/1226-sekolah-pendidikan-khas. html

http: / /www.moe.gov.my/cms/upload_files / articlefile/2014/articlefile_file_003590.pdf

http://www.moe.gov.my/en/bpkhas

http: / / www.moe.gov.my/en/programpendidikan-khas-integrasi-informasiprogram

http:/ /www.moe.gov.my/my/profil-bahagian http://www.spe-ed.net/new.php

Jabatan Kebajikan Masyarakat. 2014. Buku Garis Panduan Pendaftaran OKU. JKM: Kuala
Lumpur.

Jabatan Kebajikan Masyarakat. Laporan

Statistik Jabatan Kebajikan Masyarakat 2014. JKB: Kuala Lumpur.

Kementerian Pembangunan Wanita, Keluarga dan Masyarakat. 2016. Pelan Tindakan OKU 2016-2022. KPWKM: Putrajaya.

Kementerian Pendidikan Malaysia.

Buku Data Pendidikan Khas. Bahagian Pendidikan Khas, KPM: Putrajaya.

Kementerian Pendidikan Malaysia.2015. Buku Panduan Pengoperasian: Program Pendidikan Khas Integrasi. Bahagian Pendidikan Khas, KPM: Putrajaya.

Kementerian Pendidikan Malaysia. 2015. Kod Amalan Pendidikan Murid Berkeperluan Khas. Bahagian Pendidikan Khas, KPM: Putrajay.

Kementerian Pendidikan Malaysia. 2012. Laporan Awal Pelan Pembangunan Pendidikan Malaysia 2013 - 2025. KPM: Putrajaya.

Lineker Ak Takom, Ferlis Hj. Bahari \& Nurul Hudani Md. Nawi. 2014. Peranan atau Tanggungjawab jabatan kebajikan masyarakat Dalam Menangani Isu Pengabaian dan Penderaan Dalam Kalangan Anak OKU. Kesihatan mental Ibu Bapa Kanak-Kanak OKU:

Kajian Awal. Seminar Kebangsaan Integriti Keluarga 2014, 11Disember 2014, Falkuti Psikologi dan Pendidikan, Universiti Malaysia Sabah.

Shamsul Amri Sallehuddin. 2009. Penderaan Kanak-Kanak Kurang Upaya : Satu Kajian Prevalens (Pengalaman Dan Persepsi Kanak-Kanak) Di Institusi Khas Di Semenanjung Malaysia. Tesis Sarjana Sains. Universiti Sains Malaysia.

Siti Hajar Abu Bakar, Noralina Omar, Abd Hadi Zakaria \& Haris Abd Wahab. 2012. Intervensi Sosial Untuk Komuniti Tersisih: Ke Arah Pembangunan Ummah(Social Intervention For Marginalized Community: Towards The Development Of Ummah) . Jurnal Hadhari 4 (2):29-44. Department Of Islamic Development Of Malaysia Jabatan 
Kemajuan Islam Malaysia), Institute Of Hadhari, Universiti Kebangsaan Malaysia.

United Nation Educational, Scientific And Cultural Organization. Examples of
Good Practice in Special Needs Education Community-Based Programs. UNESCO: Paris. 